\title{
Protein degradability of silages in the rumen estimated by NIRS*
}

\author{
J. Kański ${ }^{1}$ and Z. M. Kowalski \\ Agricultural University of Cracow, Department of Animal Nutrition \\ Al. Mickiewicza 24/28, 30-059 Kraków, Poland
}

\begin{abstract}
The feasibility of estimating in situ ruminal protein degradability parameters (A, B, C, ERD) of silages by NIRS was investigated. In situ protein degradability of maize $(\mathrm{n}=12)$, whole-crop cereal $(n=18)$ and lucerne $(n=24)$ silages was determined using two ruminally cannulated Holstein heifers. The NIRS measurements were conduced using a 19-filter spectrophotometer, InfraAlyzer 450R, in the range of 1445-2348 nm. Calibration equations based on 5 terms for all $(n=54)$ and for 3 subsets of different kinds of silages were calculated. The NIRS method can be successfully used to estimate the ERD of silages. By using small, homogenous files, the precision of estimation can be increased and the standard error of estimation decreased.
\end{abstract}

KEY WORDS: silage, protein, degradability, in situ, estimation, NIRS

\section{INTRODUCTION}

Several methods are used to estimate protein ruminal degradability (Hvelplund and Weisbjerg, 1998; Schwab et. al., 2003). All of them are time consuming, hence the continued need for a new method. Previously conducted studies (Antoniewicz et al., 1995, Hoffman et. al., 1999) showed the feasibility of using near infrared reflectance spectroscopy (NIRS) in predicting forage dry matter or protein degradability in the rumen, determined by an in situ method. The applicability of NIRS must still be proved on a wide range of feedstuffs, including silages. The aim of present study was to determine the practicability of estimating ruminal protein degradability of different silages by NIRS.

\footnotetext{
* Supported by the State Committee for Scientific Research, Grant No. 6 PO6Z 002021

${ }^{1}$ Corresponding author: e-mail: rzkanski@cyfronet.krakow.pl
} 


\section{MATERIAL AND METHODS}

The ruminal protein degradability of lucerne (LS), whole-crop (WCCS, made fromoats, triticale, barley, rye), and maize silages (MS) was determined. Maize was ensiled at full maturity, whole-crop cereal silages were made of herbages cut at different stages of maturity, and lucerne silage was made from I, II and III cuts. The plants were chopped and ensiled with microbial inoculants (WCCS silages, Microsil) or a microbial-enzymatic inoculant (LS - Feedtech). All silages were dried in a air-forced oven at $50^{\circ} \mathrm{C}$ for $48 \mathrm{~h}$ and ground to pass through a $1.5 \mathrm{~mm}$ screen. Chemical composition was determined using standard methods. In situ CP rumen degradability measurements were carried out on two ruminally cannulated Holstein heifers $(420 \pm 20 \mathrm{~kg})$. The standard diet was balanced to keep the meadow hay-to-concentrate ratio at 80:20. Approximately $3 \mathrm{~g}$ of dried samples were placed in $6 \times 11 \mathrm{~cm}$ nylon bags of $50( \pm 10) \mu \mathrm{m}$ pore size (Ankom Co, Fairport, NY). Incubations were carried out at 2, 4, 8, 16, 24, 48 and $72 \mathrm{~h}$. Washing losses from the bags $(0 \mathrm{~h})$ were determined by incubation in water at $39^{\circ} \mathrm{C}$ for $15 \mathrm{~min}$. The effective CP rumen degradability (ERD) and the degradability rate constants (A, B, C) were calculated according to Ørskov and McDonald (1979) at a ruminal outflow rate of $0.06 \mathrm{~h}^{-1}$, using the NLIN SAS procedure.

In the NIRS measurements, the original samples (reground to $1 \mathrm{~mm}$ ) were scanned twice with a 19 filter spectrophotometer InfraAlyzer 450R (Technicon), using the range of 1445-2348 nm. Spectral data were recorded as $\log 1 / \mathrm{R}$ (Rreflectance) with IDAS PC software. One calibration set: ALL $(n=54)$ and 3 small subsets: LS ( $n=24)$, WCCS $(n=18)$ and MS $(n=12)$ were studied. In the ALL set, one sample was recognized as an outlier and deleted from further calculations. Statistical calculations were performed using 5 best terms (spectral waves) in calibration equations. The predicted values were related to the corresponding data determined in situ by means of regression analysis, multiple correlation coefficient (R) and standard error of calibration (SEC).

\section{RESULTS}

In the calculation of calibration equations for predicting degradability parameters A, B, C and ERD of silages, based on 5 best fitted filters, the important regions of infrared were: 1722-1759, 2100-2190, 2230 and 2336-2346 nm. The best correlation between in situ parameters and those predicted by NIRS was found for subsets MS and LS (Table 1), being over 0.92 for A, B and ERD and over 0.86 for $\mathrm{C}$. On the other hand, the lowest $\mathrm{R}$ values were observed for parameters $\mathrm{A}$ and B ( 0.69 and 0.79 , respectively) for the WCCS subset. The correlation between in situ parameters and those predicted by NIRS for ALL set was the highest for A 
and $\mathrm{ERD}$ ( $\mathrm{R}=0.90$ and $\mathrm{R}=0.88$, respectively) but the lowest for $\mathrm{B}$ and $\mathrm{C}$ ( 0.64 and 0.53 , respectively). The standard errors of calibration (SEC) were much higher when the ALL file was considered.

Table 1. In situ protein degradability parameters ${ }^{1}$ (A, B, as $\%$ of $\mathrm{CP}, \mathrm{C}$ as $\% \mathrm{~h}^{-1}$ ) and effective rumen degradability (ERD) of silages estimated by NIRS

\begin{tabular}{|c|c|c|c|c|}
\hline & A & $\mathrm{B}$ & $\mathrm{C}$ & ERD \\
\hline \multicolumn{5}{|c|}{$\mathrm{ALL}^{2}$} \\
\hline $\mathrm{n}$ & 54 & 54 & 50 & 54 \\
\hline Range (in situ) & $59.85-91.28$ & $2.04-25.29$ & $0.01-0.89$ & $64.94-97.69$ \\
\hline $\mathrm{R}^{3}$ & 0.90 & 0.64 & 0.53 & 0.88 \\
\hline $\mathrm{SEC}^{4}$ & 3.57 & 4.79 & 0.08 & 3.50 \\
\hline \multicolumn{5}{|c|}{ MS } \\
\hline $\mathrm{n}$ & 12 & 12 & 12 & 12 \\
\hline Range (in situ) & $66.69-91.28$ & $2.04-24.31$ & $0.01-0.05$ & $72.34-92.23$ \\
\hline $\mathrm{R}$ & 0.99 & 0.99 & 0.88 & 0.99 \\
\hline SEC & 0.47 & 0.59 & 0.008 & 0.34 \\
\hline \multicolumn{5}{|c|}{ LS } \\
\hline $\mathrm{n}$ & 23 & 23 & 24 & 24 \\
\hline Range (in situ) & $59.85-82.20$ & $8.00-25.29$ & $0.03-0.40$ & $64.94-88.50$ \\
\hline $\mathrm{R}$ & 0.94 & 0.92 & 0.86 & 0.97 \\
\hline SEC & 1.90 & 2.37 & 0.06 & 1.67 \\
\hline \multicolumn{5}{|c|}{ WCCS } \\
\hline $\mathrm{n}$ & 18 & 18 & 18 & 18 \\
\hline Range (in situ) & $77.4-89.34$ & $5.2-19.47$ & $0.01-2.58$ & 83.5 - 97.69 \\
\hline $\mathrm{R}$ & 0.69 & 0.79 & 0.91 & 0.86 \\
\hline SEC & 2.86 & 2.92 & 0.40 & 2.38 \\
\hline
\end{tabular}

${ }^{1}$ A-rapidly degraded protein, B-slowly degraded protein, C-degradability rate constant of $\mathrm{B},{ }^{2}$ for abbrev. see in the text, ${ }^{3} \mathrm{R}$ - multiple correlation coefficient, ${ }^{4} \mathrm{SEC}$ - standard error of calibration

\section{DISCUSSION}

The study showed that NIRS can be effectively used for predicting rumen degradability of protein, which is in agreement with the results obtained by Antoniewicz et al. (1995) and Hoffman et al. (1999). The precision of prediction based on smaller subsets was better due to higher homogeneity. On the other hand, the subsets of maize and lucerne silages seem to be more homogeneous than WCCS. Moreover, whole crop cereal silages are characterized by very rapidly degradable protein (77-89\% of fraction A). Thus, the variation in in situ protein degradability was lower in this subset than in the others. It is noteworthy that the predicted protein degradability (ERD) estimated by NIRS was less variable than the measured in situ value, which is in agreement with the results of Hoffman et al. (1999). 


\section{CONCLUSIONS}

The results confirm that NIRS can be an alternative method for in situ determination of protein degradability in the rumen. The homogeneity of samples is one of the most important features of the calibration set.

\section{REFERENCES}

Antoniewicz A.M., Kowalczyk J., Kański J., Górska-Matusiak, Z., Nalepka M., 1995. Rumen degradability of crude protein of dried grass and lucerne forage measured by in sacco incubation and predicted by near infrared spectroscopy. Anim. Feed Sci. Tech. 54, 203-216

Hoffman P.C., Brehm N.M., Bauman L.M., Peters J.B., Undersander D.J., 1999. Prediction of laboratory and in situ protein fraction in legume and grass silages using near-infrared reflectance spectroscopy. J. Dairy Sci. 82, 764-770

Hvelplund T., Weisbjerg M.R., 1998. In vitro techniques to replace in vivo methods for estimating amino acid supply. In: E.R. Deaville, E. Owen, A.T. Adesogan, C. Rymer, J.A. Huntington, T.L.J. Lawrence (Editors). In Vitro Techniques for Measuring Nutrient Supply to Ruminants. Occasional Publication No 22. British Society of Animal Science, pp. 131-144

Ørskov E.R., McDonald I., 1979. The estimation of protein degradability in the rumen from incubation measurements weighted according to rate of passage. J. Agr. Sci. 92, 499-502

Schwab C.G., Tylutki T.P., Ordway R.S., Sheaffer R.S., Stern M.D., 2003. Characterization of proteins in feeds. J. Dairy Sci. 86, Suppl., E88-E103

\section{STRESZCZENIE}

\section{Szacowanie rozkladu białka kiszonek w żwaczu metodą NIRS}

Badania dotyczyły możliwości szacowania metodą NIRS rozkładu białka kiszonek w żwaczu. Parametry A, B, C oraz efektywną degradację białka (ERD) kiszonek z kukurydzy (n=12), całych roślin zbożowych $(n=18)$ oraz lucerny $(n=24)$ określono na 2 przetokowanych jałówkach. Pomiary NIRS przeprowadzono na 19 filtrowym spektrofotometrze InfraAlyzer 450R (zakres widma 1445$2348 \mathrm{~nm}$ ). Wyliczono równania kalibracyjne z udziałem 5 długości fal dla zbioru wszystkich kiszonek $(\mathrm{n}=54)$ oraz poszczególnych podzbiorów. Na podstawie uzyskanych wyników można stwierdzić, że metoda NIRS może być z powodzeniem zastosowana do szacowania ERD w kiszonkach. Użycie kalibracji wyliczonej dla osobnych zbiorów kiszonek może zwiększyć (R>90\%) dokładność szacowania oraz zmniejszać błąd analizy (SEC). 